\title{
DIVERSIDADE NO TESTEMUNHO: MEDALHÕES DE ZOFIA NAŁKOWSKA
}

\author{
Diversidad en el Testimonio: Medallones de Zofia Nałkowska
}

\author{
Sara Adriana VOLTOLINI \\ Universidade Federal do Paraná \\ sara_voltolini@yahoo.com.br \\ https://orcid.org/0000-0001-8423-9446
}

\begin{abstract}
RESUMO: Este artigo propõe uma leitura da antologia de contos Medaliony (Medalhões, 1946), situando-a como clássico da literatura de testemunho do Holocausto e um marco na literatura polonesa; ensejando apresentar sua escritora, a importante romancista polonesa Zofia Nałkowska (1884-1954). A escritora é impactada pelas experiências da Segunda Guerra Mundial e pelo testemunho ocular como membra da Comissão de Investigação dos Crimes de Guerra Alemães na Polônia nos meses subsequentes ao seu fim. Os oito contos surgem a partir do seu diário e dos rascunhos de relatos das testemunhas da Comissão sobre os crimes nazistas. Este cenário marca uma escrita precisa e pessoal da autora que personifica a diversidade humana desta catástrofe dentro de cenas temporais do horror. Este recorte pungente e minimalista revela diferentes faces icônicas deste trauma aliadas à sua empatia pela memória dos personagens da Shoah: vítimas e sobreviventes. PALAVRAS-CHAVE: Holocausto; Testemunho; Literatura polonesa; Zofia Nałkowska.
\end{abstract}

RESUMEN: Este artículo propone una lectura de la antología de cuentos Medallones (Medaliony, 1946), ubicándola como un clásico de la literatura testimonial del Holocausto y un hito en la literatura polaca; presentando a su escritora, la importante novelista polaca Zofia Nałkowska (1884-1954). La escritora es impactada por las experiencias de la Segunda Guerra Mundial y el testimonio ocular como miembro de la Comisión Alemana de Investigación de Crímenes de Guerra en Polonia en los meses posteriores a su finalización. Los ocho cuentos surgen de su diario y de los borradores de los testimonios de los testigos de la Comisión sobre las atrocidades de la guerra. Este escenario marca una escritura precisa y personal dela autora que personifica la diversidad humana de esta catástrofe dentro de escenas temporales de horror. Este corte conmovedor y minimalista revela las diferentes faces icónicas del trauma con su empatia a lo recuerdo del personagens del Shoah: las víctimas y los sobrevivientes. PALABRAS-CLAVE: Holocausto; Testimonio; Literatura polaca; Zofia Nałkowska. 
[...] não sou capaz de repetir nada daquela noite, além do que vi de olhos bem abertos.

Aquela noite vi seminu, encharcado de suor, um homem saindo do vagão de gado onde não havia mais ar e caindo no cascalho da rampa; traga fundo a escuridão fresca e fria do campo, cambaleia até outro homem e apoiando seus braços em mim sussurra: "Irmão, irmão..."

Tadeusz Borowski (Visita)

A obra Medaliony e a escritora e ativista política Zofia Nałkowska (1884-1954) debutam em língua portuguesa nesta leitura ensejando apresentá-las à sociedade brasileira. Tanto este clássico da literatura de testemunho do Holocausto e marco na literatura polonesa quanto sua importante escritora polonesa não têm presença em tradução e publicação no Brasil.

A antologia de contos Medalhões tem sua importância literária testemunhal intensificada pela iminência da escrita e publicação completa já em setembro de 1946, com publicações parciais anteriores no ano final da guerra, 1945, em revistas e periódicos ${ }^{1}$. É marca de sua época com mais de trinta edições em polonês e tradução para quinze línguas ${ }^{2}$. Obra conhecida daquela geração jovem e culta do pós-guerra, e das subsequentes na Polônia por sua entrada na lista de literatura obrigatória para os estudos secundários $^{3}$, junto com o romance mais conhecido e premiado de Nałkowska: Granica ${ }^{4}$ (Fronteira, 1957).

Medalhões narra em oito contos um recorte pungente e minimalista do Holocausto revelando diferentes faces icônicas da Shoah. Sua leitura permite conhecer a diversidade humana da guerra e da própria Polônia, cenário central do conflito. Esta diversidade se revela personificando vítimas, sobreviventes e perpetradores dos crimes hediondos com diferentes nacionalidades, classe social, etária e gênero em cada conto.

A escrita de Nałkowska nas cinquenta páginas de Medalhões tem muito da sua

${ }^{1}$ Cito três títulos com publicação de fragmentos da obra: semanário ilustrado de Cracóvia Przekrój (Seccional), primeira revista sociocultural de Varsóvia no pós-guerra Odrodzenie (Renascimento, logo após mudando de nome para Nowa Kultura) e o periódico em Cracóvia Twórczość (Criatividade).

${ }^{2}$ Croata, eslovaco, tcheco, alemão, esperanto, russo, holandês, turco, inglês, italiano, francês, espanhol, japonês, hebraico e sueco; cito os idiomas em ordem cronológica das publicações.

${ }^{3}$ Até hoje a obra é publicada em versão explicativa para alunos, como a edição Greg de Cracóvia, 2016.

${ }^{4}$ Recebe o Laurel de Ouro da Academia Polonesa de Literatura e o Prêmio de Literatura do Estado pelo romance no ano seguinte à publicação, sua primeira publicação aconteceu em 1936. 
famosa tessitura psíquica dos personagens aliada a um texto preciso e pessoal, fruto do impacto das experiências vividas e ouvidas desta catástrofe. Cenas temporais do horror numa descrição ascética, praticamente sem comentários da autora permeiam estes relatos testemunhais, através da ótica sensível de Nałkowska, além de uma escrita breve, que se utiliza do silêncio como recurso, características presentes também nos contos behavioristas e grotescos do escritor polonês Tadeusz Borowski ${ }^{5}$, sobrevivente de Auschwitz, outro nome fundamental da literatura de testemunho polonesa sem tradução e apresentação no Brasil (BURYŁA; KRAWCZYŃSKA; LEOCIAK, 2012).

Esta escrita testemunhal surge como um novo gênero de literatura nascido no século XX que testemunha a era de catástrofes e genocídios. Na Polônia, é parte do gênero mais amplo da reportagem literária. Este testemunho literário lida com os limites entre realidade e ficção na construção da memória, como descrito por Seligmann-Silva é "fragmentário, calcado na experiência individual e da comunidade, no apego a locais simbólicos e não tem como meta a tradução integral do passado.” (2013, p. 65). Estes traumas com os quais se lida nesta literatura são indizíveis, esta problemática das limitações da linguagem em traduzir estas memórias de violência é recorrente no testemunho como no verso do poeta polonês Jerzy Ficowski' : "então percorro cemitérios que não existem / busco palavras que não existem / corro" (FICOWSKI, 2018, p. 41).

O poeta do gueto de Varsóvia, Władysław Szlengel ${ }^{7}$ na obra $A$ janela para o outro lado (Okno na tamta strone), descreve esta luta interna na qual a testemunha oscila diante da necessidade premente de testemunhar, irreprimível e penosa:

Não quero deixar apenas os números para a estatística, quero enriquecer
(má palavra) a futura história com contribuições, documentos e
ilustrações.
$\mathrm{Na}$ parede do meu barco escrevo os poemas-documentos, aos
companheiros do meu túmulo eu lia as produções de um poeta, um poeta

${ }^{5}$ Tadeusz Borowski (1901-1951), contista, poeta, jornalista e um dos mais importantes escritores poloneses da literatura de testemunho, sem tradução no Brasil. É personagem de um ensaio do livro Mente Cativa de Czesław Miłosz (já traduzido). A epígrafe deste artigo é um trecho do conto "Visita" ("Odwiedziny") da antologia Kamienny świat (O mundo de pedra, 1948), tradução nossa.

${ }^{6}$ Jerzy Ficowski (1924-2006), poeta, ensaísta e profundo divulgador da obra de Bruno Schulz. A coletânea bilíngue elogiada A leitura das cinzas (2018) foi traduzida por Piotr Kilanowski.

${ }^{7}$ Władysław Szlengel (1912-1943) jovem poeta e ator polonês, conhecido como o poeta do gueto de Varsóvia. A coletânea A janela para o outro lado: poemas do gueto de Varsóvia (2018) traz poemas e ensaios do autor que abarcam metade de sua produção conservada após a destruição do gueto. 
anno domini 1943, que procurava a inspiração na lúgubre crónica de seus dias. [...] e os poemas, no período de uma hora, se transformaram em poemas que eu lia para os mortos. (SZLENGEL, 2018, p. 15).

Premiado e prolífico, mas pouco conhecido, o testemunho polonês é profundo ao tratar do trauma, já que a Polônia foi o epicentro geográfico da guerra e território da maioria dos campos de concentração nazistas. Suas fronteiras mudaram sensivelmente após o término e sinalizam a profunda marca deixada na sociedade polonesa e na literatura do pós-guerra, marca que se estendeu muito além dos limites físicos, na escrita literária.

O premiado poeta e dramaturgo Tadeusz Różewicz ${ }^{8}$, importante poeta que dedica sua obra à tragédia humana, e Zbigniew Herbert ${ }^{9}$, grande poeta do século XX que construía narrativas poéticas que valorizam o clássico e lutam para resgatar os valores destruídos pelo totalitarismo, são escritores poloneses engajados neste testemunho.

Hanna $\mathrm{Krall}^{10}$ e seu tema das relações entre poloneses, judeus e alemães; o romance de Gustav Herling-Grudziński ${ }^{11}$, a obra Inny świat (Um outro mundo, 1953), testemunho do Gulag, campos de trabalhos forçados soviéticos; e a poesia de Henryk Grynberg ${ }^{12}$, poeta premiado com o Kościelski são escritores ainda sem tradução. Medaliony faz parte desta lista, e a leitura proposta aqui quer cooperar para que esta rica coletânea e sua primorosa escritora saiam desta invisibilidade na literatura traduzida no Brasil.

Zofia Nałkowska, além de escritora, dramaturga, ativista social e política, também

\footnotetext{
${ }^{8}$ Tadeusz Różewicz (1921-2014) poeta e dramaturgo polonês. Duas coletâneas mistas com poemas seus: Aleksandar Jovanović na antologia Céu Vazio: 63 poetas eslavos (1996) com poemas de 11 poetas poloneses. E Quatro Poetas Poloneses (1994) traduzida por Henryk Siewierski e José Santiago Naud.
}

${ }^{9}$ Zbigniew Herbert (1924-1998), grande poeta polonês do séc. XX dedica muito de sua poética à guerra. Sua antologia de ensaios Um bárbaro no jardim (2018) foi traduzida por Siewierski e as antologias de poemas $O$ Senhor Cogito. Anotações da Casa Morta (2019) e A viagem do Senhor Cogito (2016) publicada em Katowice, na Polônia, ambas em tradução de Kilanowski.

${ }^{10}$ Hanna Krall (1935-), escritora e jornalista polonesa judia conhecida internacionalmente. O artigo Hanna Krall e os caminhos tortos da memória e da identidade (2013) Kilanowski lê um romance seu.

${ }^{11}$ Gustav Herling-Grudziński (1919-2000) escritor e jornalista polonês sobrevivente do Gulag, com leitura da obra em Passados a construir: sobre um outro mundo (2011) de Marcelo P. de Souza.

${ }^{12}$ Henryk Grynberg (1936-), escritor e ator judeu polonês com vasta obra sobre o extermínio judeu. O Prêmio Kościelski é um importante prêmio literário polonês concedido como financiador de escritores. 
é uma sobrevivente polonesa e testemunha ocular que viveu quase todo o período da Segunda Guerra Mundial em Varsóvia. Intensa em tudo que fazia, cooperava ativamente na vida cultural e literária clandestina da capital, além de ter provável participação em operações de resgate em Varsóvia ${ }^{13}$. Sob a ocupação alemã, se sustenta com uma tabacaria.

Sofre neste período com a doença e perda da mãe, Anna, com quem possuía fortes laços emocionais, morava com ela e sua irmã, a escultora Hanna. Perda que amplia sua sensibilidade diante do colapso social e da tragédia humana, especialmente do extermínio dos judeus no gueto de Varsóvia; estas experiências, registra em seu diário:

\begin{abstract}
Marchas solenes dos renunciados, saltam nas chamas, saltam no escuro. (...) eu moro perto, eu posso viver! Mas finalmente me sinto mal, finalmente mudei para outra pessoa. Como posso ser forçada a isso, estar dentro dele, aceitá-lo enquanto vivo? Não é apenas uma tortura, mas também uma desgraça. É uma vergonha terrível, não apenas compaixão. Sentimo-nos culpados por fazer qualquer esforço para sobreviver, não enlouquecer ou, de alguma forma, manter-se nesse terror. (28 de abril de 1943) (NAŁKOWSKA, 1970, p. 123, tradução nossa $\left.{ }^{14}\right)$.
\end{abstract}

Nos meses posteriores ao fim da guerra, com um pouco mais de sessenta anos, como uma das escritoras mais renomadas do seu tempo, ganha uma posição na Comissão de Investigação dos Crimes de Guerra Alemães na Polônia, responsável por documentar entre 1945 e 1946 os crimes nazistas para permitir futuras condenações de perpetradores alemães. Era responsável por registrar os relatos de sobreviventes ou testemunhas sobre os crimes nazistas e visitar locais onde estes aconteceram, como campos de extermínio.

Nasce assim Medaliony, escrito a partir dos rascunhos que a escritora produziu das conversas com sobreviventes e testemunhas e de suas experiências pessoais em Varsóvia, relatadas em seu Diário dos tempos de guerra (Dzienniki czasu wojny, 1970). Diário que escreveu dos 15 anos até seus últimos dias, ao longo de quase sessenta anos e é considerado por sua biógrafa Hanna Kirchner, na introdução da publicação dos tomos como uma "biografia rica e multilateral" (KIRCHNER, 1970, p. 1). Seu diário continha descrições e detalhes de lugares visitados, objetos e pessoas que futuramente usaria em sua ficção.

\footnotetext{
${ }^{13}$ Sua biógrafa Hanna Kirchner afirma na obra sobre sua vida.

${ }^{14}$ Seus diários são uma importantíssima obra literária, sem tradução em português, a tradução feita apenas se preocupou com a clareza das ideias, fundamentais aqui para compreender a gênese da obra Medalhões.
} 
Sua percepção da guerra já aparece em seus contos de 1917, a coletânea Tajemnice krwi (Segredos de sangue) onde reflete sobre a guerra como uma vida acelerada, portanto com seu mal concentrado: "A guerra toma em si o que está pronto antes: selvageria, miséria, sofrimento e morte” (BURYŁA, LEOCIAK, KRAWCZYŃSKA, 2012, p. 10).

Nałkowska transforma este profundo mergulho sobre as histórias de terror e crimes hediondos num dos mais importantes livros de testemunho da Shoah e uma obra canônica para os poloneses, como expresso pelo escritor judeu polonês Henryk Grynberg: "Nenhum outro conto sobre o Holocausto soa mais verdadeiro, nenhum outro relato é um testemunho melhor da verdade”. (GRYNBERG, apud GLIŃSKI, 2020, não p., tradução nossa).

Sua importância não recai apenas em sua emblemática obra, inclui sua pessoa e sua influência atemporal. Conhecida por sua elegância e atitude extraordinária diante da vida, Jan Kott $^{15}$ comenta sobre uma viagem que faz com esta senhora à Moscou em sua obra Aloes: "Ela não era apenas uma escritora, também era uma grande figura literária. [...] todos perguntavam quem era essa senhora muito exótica." (KOTT, apud DĄBROWSKA, 2010, não paginado).

$\mathrm{Na}$ vida e na literatura foi uma mulher de vanguarda, progressista, feminista e liberal da juventude à velhice. Já no início de sua carreira como escritora, aos 22 anos fica conhecida pela sua ousada fala a respeito da libertação sexual da mulher exigindo igualdade de direitos sexuais e de voto, no Congresso de Mulheres de Varsóvia ${ }^{16}$ (Zjazd Kobiet), tema do qual retornará a escrever ${ }^{17}$; sendo naquele momento casada, que obviamente não funcionaria para ela, divorciou-se duas vezes. A frase do seu discurso Chcemy całego życia (Queremos toda a vida) tornou-se símbolo da luta pelos direitos da mulher até hoje.

Filha de Wacław Nałkowski, um ilustre jornalista e geógrafo e da escritora e ativista social Anna Šafránková, nasceu com o germe do ativismo e foi uma grande apoiadora de movimentos sociais, que o fez militando na Sociedade de Ajuda aos presos e em movimentos feministas. Expande suas atividades no pós-guerra como figura política importante tornando-se membra do Conselho Popular Nacional, do Parlamento Comunista e deputada da Assembleia Legislativa Sejm, onde atuou na Comissão de Arte e Cultura.

\footnotetext{
${ }^{15}$ Jan Kott (1914-2001), poeta, tradutor e teórico do teatro polonês, Rozmowy Zofii Natkowskiej.

${ }^{16} \mathrm{Zjazd}$ Kobiet aconteceu em homenagem ao $40^{\circ}$ aniversário da obra de Eliza Orzeszkowa.

${ }^{17}$ Organizacja erotyzmu (A organização do erotismo). Wiadomości Literackie, v. 9, n. 25, 19 jun. 1932.
} 
Também atuou na Comissão de Defensores da Paz e na Liga de Combate ao Racismo.

Cresce numa casa com constantes encontros de um círculo valioso de pensadores da época, ambiente que a preparou para ser uma grande anfitriã da inteligencja polonesa. Intelectuais, políticos, militares e artistas, renomados ou não, circulavam no salão mais frequentado de Varsóvia. Gombrowicz ${ }^{18}$, amigo de Nałkowska fala de suas habilidades como salonnière:

\begin{abstract}
Eu já falei sobre visitas a Zofia Nałkowska? Sua casa era o cerne da vida literária em Varsóvia. [...] Em um sofá, sentava a Sra. Zofia, a única integrante feminina da Academia de Literatura, que liderava a conversa como se fosse uma das matronas distintas dos tempos anteriores à guerra. [...] Não havia dúvida de que a inteligência e as maneiras dessa mulher notável moldavam a qualidade da conversa e lidava com sucesso com uma grande variedade de personagens que participavam das reuniões (GOMBROWICZ, 1995, p. 207).
\end{abstract}

Gombrowicz afirma em seu diário que recebia seus conselhos como escritor em ascensão, Witkacy lhe dedicou a pintura de seu retrato em pastel sobre o papel, em 5 de junho de 1930. Conhecida como descobridora de novos talentos literários e interessada por trabalhos marginais e às vezes também pelo artista. Sua maior descoberta, Bruno Schulz ${ }^{19}$, era conhecido como seu protegido. Foi fundamental para a publicação da primeira obra Sklepy Cynamonowe (Lojas de Canela) e contribuiu para lhe dar visibilidade como escritor, ganhando entusiastas como Witkacy e Tuwim ${ }^{20}$, além dela mesma.

$\mathrm{Na}$ escrita participou de importantes movimentos literários, em seus primeiros romances segue a poética modernista do movimento Młoda Polska ${ }^{21}$ (Jovem Polônia) representada pelo decadentismo com forte marca feminista. Após a Primeira Guerra Mundial, seus romances ganham novo enfoque, são "fruto de uma observação aguda

${ }^{18}$ Witold Gombrowicz (1904-1969), escritor e dramaturgo polonês de vanguarda, morou 24 anos em Buenos Aires. Há uma coletânea de contos, Bakakai e 3 romances traduzidos: Ferdydurke, Cosmos e Pornografia. Trecho citado de Wspomnienia polskie. Wędrówki po Argentynie (Memórias Polonesas. Vagando pela Argentina, 1977).

${ }^{19}$ Bruno Schulz (1892-1942), contista e pintor polonês judeu de estilo original. Obras traduzidas: Lojas de Canela (1996), Sanatório (1994) e Ficção completa (2012) por H. Siewierski.

${ }^{20}$ Julian Tuwim (1894-1953), importante poeta experimental polonês, escreveu muitos poemas infantis.

${ }^{21}$ Młoda Polska (Jovem Polônia), movimento literário com o decadentismo e o realismo como correntes. 
e sensível da situação social e política da Polônia" (2000, p. 156) conforme escrito por Henryk Siewierski na História da Literatura Polonesa ${ }^{22}$. A riqueza de sua obra está nas análises da psique dos personagens e das relações que acrescenta à tradição realista juntamente com Maria Dąbrowska ${ }^{23}$. Foi como membra do grupo literário Przedmieście ${ }^{24}$ junto com nomes como Gustav Herling-Grudziński que explorou este olhar sobre as minorias sociais (SIEWIERSKI, 2000).

A maior parte de sua obra escreve no período entre guerras, em que milita ativamente pela Associação Profissional de Escritores Poloneses, sendo a mais eminente escritora polonesa do entre guerras. Foi a primeira mulher a entrar para a Academia Polonesa de Letras e a ser integrante e depois presidente do PEN Club polonês. Ao longo da carreira literária, recebeu diversas honrarias, dois prêmios nacionais, além do Laurel de Ouro da Academia Polonesa de Literatura pelo seu romance mais notável Granica (Fronteira, 1936). No pós-guerra foi editora do semanário Kuźnica.

Seu título como dama da literatura polonesa não veio por acaso, escreveu quinze romances, doze coleções de contos e novelas, três peças de teatro elogiadas pela crítica e um diário de vida de seis volumes considerado por alguns como sua maior obra. Até seus últimos dias, continuava uma vida altamente produtiva, escrevendo, participando de grupos literários e eventos sociais.

Ryszard Kapuściński25 dá razão ao título de dama: "Pego os livros de Nałkowska como se estivesse pegando um copo de água da nascente. É o único polonês em que confio, o único polonês em que posso, com confiança, fundamentar meus próprios pensamentos" (KAPUŚCIŃSKI, apud KIRCHNER, 1970, p. 4). Gombrowicz resume e a eterniza como escritora e mulher:

\footnotetext{
${ }^{22}$ A obra foi publicada em 2000, pela editora da Universidade de Brasília e é referência em sua proposta.

${ }^{23}$ Maria Dąbrowska (1889-1965), romancista polonesa, contemporânea no realismo psicológico de Zofia.

${ }^{24}$ Przedmieście (Subúrbio), grupo literário da prosa polonesa, que pesquisou os problemas proletários.

${ }^{25}$ Ryszard Kapuściński (1932-2007), escritor e jornalista polonês, mestre da reportagem literária com as obras publicadas pela Cia das Letras: Imperium (1994), Ébano (2002), O Imperador (2005), Minhas viagens com Heródoto (2006), A guerra do futebol (2008) e O xá dos xás (2012), citado por Hanna Kirchner na introdução da publicação dos diários de Nałkowska do período de guerra e pós-guerra.
} 
Há uma boa razão pela qual seu estilo é a força capital de sua arte e um dos poucos exportáveis em nossa literatura nacional. Nalkowska é estilo e não há diferença entre o estilo de seus livros e sua vida. Embora ela seja amplamente considerada uma intelectual, não há realmente quebracabeças para ela. Na análise final, o que é essencial para ela é apenas a atitude adotada em relação ao quebra-cabeça, o sentimento particular que um problema evoca quando se depara com sua pessoa. Apesar das aparências em contrário, ela é uma grande egoísta, para quem todo o assunto se resume a isso - como resgatar sua própria humanidade das armadilhas da civilização contemporânea. (GOMBROWICZ apud KUPREL, xii).

Esta humanidade se acentua diante do cenário da Segunda Guerra Mundial e de suas experiências que marcam uma nova escrita precisa e pessoal da autora na antologia Medalhões. Quando Nałkowska se propõe a identificar personagens particulares, ela o faz elencando representantes de distintos grupos deste ambiente hostil, personagens que reunidos criam uma imagem da diversidade humana da Shoah. Uma obra que condensada ocupa menos de cinquenta páginas, ser capaz de demonstrar aspectos tão diversos da Segunda Guerra Mundial, com linguagem acessível e profunda é um feito unique.

Em vez de marcar a maior área possível de criminalidade, Nałkowska permanece - como se viu - um detalhe salutar, com uma única biografia e um evento específico. Isso exigia a limpeza da biografia dos personagens retratados de todas as informações desnecessárias, todos os elementos irrelevantes que iam além do que era absolutamente necessário. Ao eliminar consistentemente todas as informações e excedentes estilísticos, Nałkowska - e isso inclui a grandeza de sua prosa - dá vida ao destino e aos personagens extremamente expressivos, penetrando em nossa memória e permanecendo nela como uma herança indesejada. (BURYŁA, LEOCIAK, KRAWCZYŃSKA, 2012, p. 427).

Nałkowska dá voz a mulheres, judias e polonesas, um pai de família, adultos e crianças, professores e estudantes, e ao grupo mais brutalmente silenciado: aos não sobreviventes. O impacto da obra está na tessitura do texto, com uma escrita direta, tão breve e silenciosa que não se percebe suas interferências, exige um leitor mais atento. Os judeus e aqueles que pereceram são vividamente simbolizados através destes concisos e intensos personagens que surgem como retratos da Shoah.

A passagem de minhas emoções e a passagem de pessoas que continuam saindo e desaparecendo, que não deixam nada para trás: esse é o único impulso por trás da minha escrita. Como sempre, não me preocupo com eventos históricos, destino de nações inteiras, fatos passando em segundo plano - não é isso que me tenta, pois os outros vão lidar com 
isso de uma maneira muito melhor -, mas com a vida como eu já vi e experimentei a mim mesmo, que está totalmente fadado ao fracasso. [...] E falho em atingir o objetivo de manter registros. (1 de abril de 1942) (NAŁKOWSKA, 1970, p. 97).

A crítica literária sobre a obra discute sua característica mais marcante, a quebra da estrutura tradicional da prosa literária, se ausentando quase que completamente de tecer comentários na escrita (BURYŁA; KRAWCZYŃSKA; LEOCIAK, 2012). Esta característica é muito questionada na recepção da obra, mas na percepção de Grynberg "Nenhum outro conto do Holocausto soa mais verdadeiro, nenhum outro relato é um testemunho melhor da verdade" (GRYNBERG, apud GLIŃSKI, 2020, não p.).

Sua recepção na Polônia rapidamente a elevou a obra de referência sobre a Segunda Guerra Mundial, lida pela sociedade culta polonesa e pela juventude em todas as escolas, sendo parte da imagem coletiva que os poloneses têm da Segunda Guerra Mundial (GLIŃSKI, 2020). Mas é tida como uma obra que apresenta o sofrimento humano e, portanto, polonês na guerra. Esta análise humanista sobre a obra se cristaliza ao longo do tempo, presente nas capas das obras com o triângulo polonês de prisioneiros do lager, nas introduções e na obra comentada e publicada para uso escolar (NAŁKOWSKA, 2016).

Esta percepção dificultou novos olhares sobre a obra como pondera uma nova e importante obra no universo letrado polonês sobre a recepção da obra na Polônia ${ }^{26}$. O editor do livro que trata exclusivamente sobre Medalhões, Tomasz Żukowski, reforça que a vitimização dos poloneses os impediu de ver sua cumplicidade.

Colocando-se na posição de vítimas, em linha com as vítimas da Shoah, a maioria rejeita as perguntas sobre seu próprio comportamento em relação aos judeus e seu significado - isto é, as atitudes que tornaram possível, facilitou ou complementou os planos de extermínio hitleristas. Esse tipo de inclusão na humanidade [...] combina com o ouvido surdo e oculta a diferença produzida. Este foi o caminho seguido pela recepção polonesa dos 'medalhões'. (ŻUKOWSKI apud GLIŃSKI, 2020, não paginado).

Medalhões é acima de tudo uma obra de testemunho da Shoah, e como tal seu leitmotiv é o extermínio judeu reforçado pelos 4 contos com personagens claramente judeus, além de outro tematizando o antissemitismo polonês. Esta prevalência não passa despercebida na leitura da obra e pode suscitar novas análises, muito ricas que ampliam o espaço e as possibilidades de discussões até então sobre ela.

${ }^{26}$ Zagłada w Medalionach Zofii Natkowskiej 2016: Tekst i Konteksty. 
A recepção da obra no exterior foi afetada por exemplo, pela crítica negativa e sexista, escrita por Gustaw Herling-Grudziński para o semanário londrino Wiadomości como segue:

\begin{abstract}
Nałkowska escreveu o masculino Medalhões [...] Eu não acho que tenho que repetir que essa divisão não tem nada a ver com julgamentos avaliativos, feministas profissionais devem imediatamente conter o fluxo crescente de protestos e indignações. O que quero dizer aqui são as características distintivas particulares, que são positivas. [...] a simplicidade pretendida do livro se torna uma simplificação não intencional". (HERLING-GRUDZIŃSKI, 1947).
\end{abstract}

O primeiro e mais famoso dentre os contos, "Profesor Spanner" ("Professor Spanner"), narra as atividades no Instituto Anatômico de Gdańsk, que através do seu diretor, o doutor alemão Spanner a serviço do Reich conduz a conservação de cadáveres para a Academia Médica. O ponto central da narrativa é a produção clandestina de sabão a partir da gordura humana, processo em que também atua o preparador de cadáveres e narrador do conto. A narrativa é conduzida em um interrogatório da Comissão de Investigação.

Estes fatos narrados são eventos históricos reais, apesar de controversos: Nałkowska visitou o Instituto e participou dos interrogatórios, de 10 a 13 de maio de 1945, conforme os registros em seu diário. Rudolf Spanner ficou famoso no pós-guerra pela descoberta desta fabricação de sabão a partir da gordura humana.

Duas cenas chamam a atenção neste conto: a benção de uma guilhotina e de uma forca dentro da Prisão de Gdańsk numa celebração solene, quase religiosa; e o interrogatório final de dois médicos e colegas de Spanner sobre sua capacidade em fabricar sabão de gordura humana. Suas respostas realçam uma atitude mecanizante e não reflexiva dos personagens sobre o que executavam, este "mal banal" é tema fundamental nas discussões futuras que surgem sobre a Shoah discutidas por Hannah Arendt.

Um de seus colegas o inocenta como um disciplinado, e portanto, cumpridor de ordens, membro do Partido; e o outro não o isenta da produção, mas sublima seu ato lúgubre pela causa: "[...] a Alemanha experimentou naquele tempo uma grande escassez de gorduras. E por tal situação econômica do país, e o bem do Estado podem tê-lo obrigado a isso."27 (NAŁKOWSKA, 2017, p. 16, tradução nossa).

\footnotetext{
${ }^{27}$ Original: “[...] że Niemcy przeżywały wówczas wielki brak tłuszczów. Więc wzgląd na stan ekonomiczny kraju, na dobro państwa mógł go do tego skłonić.”.
} 
"Professor Spanner" não só introduz a antologia, mas situa toda a obra pela referência direta à Comissão e seu trabalho de investigação. Este conto representa a presença étnica e ideológica alemã-nazista e seus colaboradores, sejam alemães nas posições de autoridade ou colaboracionistas poloneses, como o jovem narrador. A ideologia pseudocientífica nazista fica evidente nesta descrição e na frase icônica do jovem preparador sobre o uso do sabão pronto:

- Sim, contei em casa... No início até um colega viu: dava calafrios quando me lavava com isso. Em casa a mãe também tinha repulsa. Mas espumava bem, então usava-o para a roupa. Eu me acostumei, porque era bom...

Em seu rosto magro e pálido apareceu um sorriso indulgente.

- Na Alemanha, pode-se dizer, que as pessoas sabem fazer qualquer coisa - com nada... (NAŁKOWSKA, 2017, p. 15, tradução nossa). ${ }^{28}$

(Original: - Owszem, mówiłem w domu... Z początku nawet jeden kolega widział: miałem dreszcz, że można się tym myć. W domu mama też się obrzydzała. Ale się dobrze mydliło, więc go używała do prania. Ja się przyzwyczaiłem, bo było dobre...

Na jego chudej, wybladłej twarzy pojawia się wyrozumiały uśmiech.

- W Niemczech, można powiedzieć, ludzie umieją coś zrobić - z niczego...)

Esta frase final reproduz uma ideologia racial que vê o sabão como algo útil, portanto, alguma coisa, já os corpos humanos mortos são inúteis, portanto, nada. Esta percepção distorcida da realidade humana, incorporada a uma narrativa dura com descrições do grotesco daquela realidade, é uma das marcas dos contos.

Os seis contos centrais ganham uma estética mais específica, pois surgem a partir de personagens únicos, alguns seus próprios narradores, outros na narração de testemunhas, mas que têm sua própria voz compondo a narrativa. Contos quase sem comentários da escritora ganham vida em cenas pontuais e simbólicas dentro do universo da Shoah. Estas cenas aproximam o leitor da catástrofe dando rosto, nem sempre nome, gênero (em sua maior parte feminino) e faixa etária. Este recurso de aproximação usado pela autora sensibiliza diante do terror inaudito vivido pelas vítimas e sobreviventes.

"Dno" ("Fundo") é o segundo conto e sua trama demonstra a empatia pela

${ }^{28}$ Todas as traduções dos contos são de minha autoria, em fase de revisão, parte do projeto monográfico que se propõe a traduzir e analisar os oito contos de Medalhões a partir do original polonês em contraste com as traduções para o inglês e para o espanhol, a orientação é do Prof. Dr. Piotr Kilanowski da UFPR. 
memória destas personagens tão violentamente desumanizadas, sobreviventes ou não. A personagem inicia o conto se auto descrevendo: "E nada mais importa pra ela, apenas compaixão. Que as pessoas se compadeçam dela, pois passou por muita coisa e é uma mãe que perdeu dois filhos. Não sabe ao certo, se morreram." ${ }^{29}$ (NAŁKOWSKA, 2017, p. 17, tradução nossa). Esta mulher idosa descrita com muita delicadeza sem notícias dos dois filhos e do marido; lembra como sobreviveu ao horror do lager e descreve cenas aterradoras dos que não sobreviveram, ela mesma solicita a sensibilidade do olhar do leitor mais de uma vez ao longo do conto.

"Fundo" toca no extremo do desumano, sobre os prisioneiros da prisão de Pawiak deixados como alimento de ratazanas ainda vivos e a fome em seu mais vil limiar ao encarar o outro como comida, e este outro morto em bunkers. Cenas inomináveis contadas em tom de conversa pessoal entre pausas e palavras abafadas de uma mãe órfã e só: "Agora se cala por um longo tempo. Reflete, como se quisesse contar algo mais. Mas não pode. Recompõem-se"30 (NAŁKOWSKA, 2017, p. 21, tradução nossa).

Ao mesmo tempo é neste conto que vemos traços do trabalho da clandestinidade e da resistência, representada pelos filhos da narradora que atuavam ativamente, a filha como professora e o filho treinando outros e tendo participado do Levante de Varsóvia. A personagem cita outra resistente que conhece na prisão, mas enlouquece:

Aquelas que enlouqueceram, pulavam em nós, nos mordiam e agrediam. Uma delas, que nunca contou nada em Pawiak onde suportara os piores interrogatórios, agora gritava alto sobrenomes de pessoas, revelava lugares, onde haviam armas enterradas em caixotes, em qual floresta, no cruzamento de um caminho, em qual povoado. Dizia, só o que podia lembrar. Passamos tanto medo, que tudo parecia perdido. Mas eles nem sequer a escutaram, apenas atiraram nelas uma a uma. (NAŁKOWSKA, 2017, p. 22, tradução nossa).

(Original: Jak zwariowały, to rzucały się na nas, gryzły nas i szarpały. Jedna między nami, która nic nie powiedziała na Pawiaku przy najgorszym badaniu, teraz krzyczała na głos nazwiska ludzi, wymieniała miejsca, gdzie jest zakopana broń w skrzyniach, w jakim lesie, na skrzyżowaniu dróg, w jakiej wsi. Mówiła, co tylko mogła sobie przypomnieć. Takeśmy się bały, że wszystkich zgubi. Ale oni już tego nie słuchali, tylko je jedną po drugiej zastrzelili.)

\footnotetext{
${ }^{29}$ Original: "O nic jej nie chodzi, tylko o życzliwość. O to, żeby ludzie byli dla niej życzliwi, bo dużo przeszła i jest matką, która straciła dwoje dzieci. Nie wie na pewno, czy umarły.”.

${ }^{30}$ Original: “Teraz zamilkła na dłuższą chwilę. Namyślała się, jakby coś jeszcze chciała dodać. Ale nie mogła. Otrząsnęła się.”.
} 
Esta solitária narrativa possui apenas um pequeno traço de companhia, em falas curtas da narradora se dirigindo a uma "senhora" enquanto fala, num caso especificamente perguntando "Como?", dando a impressão de um comentário externo, e continuando seu relato. Friso que este conto mostra alguns cenários da guerra exclusivos de mulheres, como o campo de concentração feminino e a fábrica de munições, cenários que também aparecem no conto "Wiza"; portanto, com as Gestapos alemãs e as kapos polonesas. Esta escolha pela representação de um universo quase só de mulheres está ligada exatamente à afinidade de Nałkowska com personagens femininas.

Ao final do conto, após tantos retratos macabros: "Está sentada sem mover-se, pesando, o que ainda pode contar. E de repente se anima. Direi algo mais senhora, isto é interessante."31 (NAŁKOWSKA, 2017, p. 21, tradução nossa) E relata o efeito mortal do confinamento apertado, da falta de ar e da sede na longa viagem de transporte entre a prisão de Pawiak e o campo de concentração feminino de Ravensbrück em vagões de gado. A cena aterradora descreve a reação de um oficial alemão que não imagina o que encontraria ao abrir a porta:

Nenhuma gota d'água, nenhuma possibilidade de sair, tudo fazíamos ali, nas pernas. E assim dormíamos em pé, não podíamos sentar de tão apertadas. E assim seguimos durante sete dias. No caminho deixaramnos em uma via lateral. O trem parou por três horas. Então começamos todas a uivar com vozes inumanas por água. Porque nos transportavam no calor naquele vagão lacrado, estávamos molhadas de suor, com rostos negros de poeira, nossas roupas fediam, as pernas imundas de esterco. Por isso começamos a uivar como animais.

Então chegou um oficial alemão de outro trem, que transportava soldados feridos e ordenou abrir o vagão. Mas fomos escoltadas por ucranianos. E disseram, que não era permitido, pois éramos criminosos. Então ele chamou dois oficiais, porque estava interessado, no que estava ali dentro. Descerraram o vagão e então nos viu.

Senhora! Quando nos viu, seus olhos se arregalaram, estirou os braços assim, de medo! Como se assustou ao nos ver! Parecia um javali!

(NAŁKOWSKA, 2017, p.21-22, tradução nossa).

(Original: Ani wody, ani możności wyjścia, wszystko tak na stojący, po nogach. I tak spałyśmy na stojący, nie mogłyśmy usiąść z samej ciasnoty. I tak jechałyśmy siedem dni.

Po drodze nas postawili na bocznym torze. Pociąg stał trzy godziny. Wtedy zaczęłyśmy wszystkie wyć do wody nieludzkimi głosami. Bo wieźli nas $\mathrm{w}$ tym zaplombowanym wagonie w upał, byłyśmy mokre

\footnotetext{
${ }^{31}$ Original: "Siedziała bez ruchu, namyślała się, co by jeszcze powiedzieć. I nagle się ożywiła.

- Jeszcze pani coś powiem, to będzie ciekawe.”.
} 
od potu, czarne na twarzy od kurzu, ubranie na nas śmierdziało, nogi miałyśmy ubabrane w gnoju. Więc zaczęłyśmy wyć jak zwierzęta.

Wtedy przyszedł niemiecki oficer od drugiego pociągu, który wiózł rannych żołnierzy, i kazał wagon otworzyć. Ale nas konwojowali Ukraińcy. I powiedzieli, że nie wolno, że to jadą bandyci. Wtedy on zawołał drugich oficerów, bo był ciekawy, co tam jest. Odplombowali wagon i wtedy nas zobaczył.

Proszę pani! Jak nas zobaczył, jego oczy zrobiły się okrągłe, ręce o tak rozcapierzył ze strachu! Tak się nas przeląkł! Wyglądał jak dzik!)

O parágrafo final remonta esta angústia constante do sobrevivente ao tentar resgatar uma memória incompleta, que mantém os mortos no anonimato, no entanto está associada a uma atitude afetuosa diante das lembranças das vítimas que conserva e da fragilidade alheia:

\section{Entristece.}

- Assusta-me, que não me recorde como se chamavam. Porque ali havia valorosas mulheres, mulheres dignas. Pode ser que agora suas famílias as procurem, como eu procuro meus filhos. E eu não consigo lembrar, quem eram.

Veja senhora, veja! Até um alemão, se assustou, ao nos ver. Não é de estranhar, que elas não puderam resistir. (NAŁKOWSKA, 2017, p. 23, tradução nossa).

(Original: Posmutniała.

- Strach mi, że nie zapamiętałam, jak się nazywały. Bo tam były wartościowe, zasłużone kobiety. Może ich teraz szuka rodzina, jak ja szukam moich dzieci. A ja nie mogę sobie przypomnieć, kto to był. Widzi pani, widzi pani! Nawet Niemiec, i to się przeląkł, jak nas zobaczył. Cóż to dziwnego, że one nie mogły wytrzymać.)

"Kobieta Cmentarna" ("A mulher do cemitério") é o terceiro conto e aquele que sinaliza o antissemitismo polonês arraigado na percepção de pessoas comuns, assim como "Przy torze kolejowym" (“Ao lado da ferrovia"). Sua personagem é uma mulher polonesa que trabalha no cemitério ao lado do gueto de Varsóvia separados apenas por um muro. Sua percepção da realidade não se altera, ainda que tenha lhe chocado a realidade do extermínio ao seu lado (ŻUKOWSKI, 2016).

"A mulher do cemitério" é um conto que apresenta com consistência o ascetismo estético adotado pela autora. A arte aqui representada pelo estilo lacônico de escrever, sem interferências externas, traz duas cenas importantes, uma delas do incêndio do gueto: "Mesmo que não vimos, ouvimos. Se ouviu como se algo mole deu contra o solo. Plaf, 
plaf... Não param de pular, preferem pular que queimarem vivos..."32 (NAŁKOWSKA, 2017, p. 29, tradução nossa) O título da obra surge a partir de um recorte deste conto, quando a narradora personagem descreve os bombardeios:

Depois veio o tempo em que caíram projéteis/bombas sobre o cemitério. Estátuas e medalhões em pedaços jaziam ao longo das avenidas. As tumbas, com seus interiores abertos, mostravam os mortos em caixões destroçados.

Mas mesmo diante disto a mulher do cemitério conservava sua calma natural.

- Não lhes acontecerá nada - dizia - Garanto que não morrerão uma segunda vez. (NAŁKOWSKA, 2017, p. 28, tradução nossa).

(No original: Później przyszedł czas, gdy na cmentarz spadały pociski. Posągi i medaliony potłuczone leżały wzdłuż alei. Groby z otwartymi wnętrzami ukazały w pękniętych trumnach swoich umarłych.

Ale kobieta cmentarna wobec tej sprawy również zachowała wrodzony spokój.

- Nic im nie będzie - powiedziała. - Nie umrą przecież drugi raz.)

E a morte é tema central no conto, inclusive torna-se sujeito personificado dentro de um espaço que a guarda e homenageia, reflexões sobre as diferenças desta morte natural e comum como dito no conto e a morte coletiva desta nova realidade crua. Esta ampliação da morte é reforçada pela perda significativa da mãe de Nałkowska, que a abalou profundamente já em 1943. Uma de suas motivações para este conto está exatamente em suas visitas ao cemitério de Varsóvia já no final de 1943 até o túmulo de sua mãe, quando possivelmente teve um encontro com a cuidadora das flores e dos túmulos.

De toda parte chegam notícias de óbitos. Morreu P. no campo, morreu K. nalguma pequena estação de trem, capturada na rua e transportada pra fora. Pessoas morriam de todas as maneiras, sob qualquer pretexto. Parece que não há ninguém vivo, que não há em que se obstinar, não há em que insistir. Está em toda parte esta morte. No subterrâneo das capelas do cemitério, caixões estão alinhados e aguardam por assim dizer na fila em tempo de seu enterro. A morte costumeira, pessoal, perante a enormidade da morte coletiva parece inadequada. Mas coisa mais vergonhosa é viver. (NAŁKOWSKA, 2017, p. 24-25, tradução nossa).

(Original: Zewsząd nadchodzą wiadomości o zgonach. Umarł P. w

\footnotetext{
${ }^{32}$ Original: “- I nawet jak tego nie widać, to my słyszymy. To słychać tak, jakby coś miękkiego klapnęło. Wciąż tak wyskakują, wolą wyskoczyć, niż się za życia spalić w ogniu...”.
} 
obozie, umarła K. na jakiejś małej stacji kolejowej, schwytana na ulicy i wywieziona. Ludzie giną na wszelkie sposoby, wedle wszelkich kluczów, pod każdym pretekstem. Wydaje się, że nie żyją już wszyscy, że nie ma się przy czym upierać, nie ma przy czym obstawać. Tyle jest wszędzie tej śmierci. W podziemiach kaplic cmentarnych trumny stoją rzędami i oczekują niejako w ogonku na czas swego pogrzebu. Śmierć zwyczajna, osobista, wobec ogromu śmierci zbiorowej wydaje się czymś niewłaściwym. Ale rzeczą bardziej wstydliwą jest żyć.)

O antissemitismo da polonesa é trazido para lembrar de sua responsabilidade moral como representante dos poloneses durante a guerra. E como testemunha passiva diante de um trauma intraduzível em palavras sua atitude é contrastada com a beleza do lugar, uma beleza baseada na imutabilidade e no silêncio.

- Depois de tudo também são pessoas, e dá pena - conta - Mas olhe, para nós é melhor que os alemães acabem com eles. Odeiam-nos mais que aos alemães...

Parece ofendida pelas minhas palavras ingenuamente persuasivas.

- Quem disse o quê? Não é necessário que alguém diga. Sei por mim mesma. E qualquer que os conheça dirá o mesmo: que se os alemães perdem a guerra, os judeus matam a todos... Você não acredita? Mas se os próprios alemães dizem-no. E também foi dito pela rádio...

Ela sabe melhor que eu, por alguma razão precisa acreditar assim. (NAŁKOWSKA, 2017, p. 28-29, tradução nossa).

(No original: - To także przecież ludzie, więc ich człowiek żałuje wyjaśniła. - Ale, proszę pani, dla nas lepiej, jak ich Niemcy wyniszczą. Oni nas nienawidzą gorzej niż Niemców...

Zdawała się urażona mymi słowami naiwnej perswazji.

- Jak to, kto mówił? Nikt nie potrzebował mówić. Sama wiem. I każdy pani powie to samo, kto ich zna. Że niechby tylko Niemcy wojnę przegrały, to Żydzi wezmą i nas wszystkich wymordują... Pani nie wierzy? Nawet same Niemcy to mówią. I radio też mówiło...

Wiedziała lepiej, do czegoś jej była potrzebna ta wiara.)

O trecho mais significativo no sentido de reflexão filosófica neste conto foi retirado integralmente do seu diário, e se refere à revolta do gueto de Varsóvia, pertinente aqui por fazer parte do mesmo cenário, visto duma perspectiva semelhante, já que Nałkowska em outro trecho de seus diários diz que podia ver o gueto da janela do bonde.

A realidade é insuportável, porque não é totalmente experimentada; não é totalmente visível. Ela chega a nós em frações de eventos, fragmentos de relatos, ecos de tiros - horríveis e impenetráveis - nas nuvens de 
poeira, em incêndios, que, como a história diz "reduziu tudo a cinzas", embora ninguém realmente entenda essas palavras. Essa realidade, distante e acontecendo ao lado, é suportável. O que você não pode suportar são seus pensamentos. (28 de abril de 1943) (NAŁKOWSKA, 1947, p. 30, tradução nossa).

"Przy torze kolejowym" (“Ao lado da ferrovia”) é o quarto conto sua personagem é uma mulher judia e a única não sobrevivente. Como tal, sua narrativa é contada por um narrador testemunha ocular de sua coragem última; este não é nomeado, mas descrito nestas palavras: "Só é possível conhecê-la hoje pelo relato de um homem, que viu e que não pode compreender, também vive só em sua memória." ${ }^{33}$ (Nałkowska, 2017, p. 33, tradução nossa). A mulher tenta fugir de um vagão de gado em movimento, que transporta judeus para campos de concentração, na busca pueril de salvação. Nesta busca por alternativa é baleada por alemães, cai sentada e ali fica, ao lado da via férrea.

"Ao lado da ferrovia" é um conto que se propõe mostrar como alguns poloneses na inércia de suas ações contribuíram para os acontecimentos sombrios. Rapidamente se avolumam pessoas ao seu redor, há uma iniciativa de ajuda pontual de uma senhora lhe oferecendo leite e pão e outro cigarro e vodca a seu pedido. O temor da retaliação por ajudar uma judia, penalizada também com morte, mantêm os poloneses sem ação. Os habitantes locais poloneses e inclusive a polícia local que se apresenta agem como se não fosse humana, essa segregação naturalizada está descrita:

Ela estava estendida em meio as pessoas, mas não esperava ajuda. Jazia como um animal ferido em uma caçada que tivessem esquecido de arrematar. Estava bêbada, cochilava. A força, que a mantinha separada de todos eles por um círculo de terror, era invencível. (NAŁKOWSKA, 2017, p. 34, tradução nossa).

(Original: Leżała pośród ludzi, ale nie liczyła na pomoc. Leżała jak zwierzę ranne na polowaniu, które zapomniano dobić. Była pijana, drzemała. Nieprzeparta była ta siła, która odgradzała ją od nich wszystkich pierścieniem przerażenia.)

Não havia a ciência nem a presença de nenhuma autoridade alemã, ela estava baleada; mas em conversas ao seu redor, sem dirigir nenhuma palavra a ela: "Falavam

\footnotetext{
${ }^{33}$ Original: "Daje się poznać już dziś tylko w opowiadaniu człowieka, który to widział i który nie może tego zrozumieć, żyje też już tylko w jego pamięci.".
} 
como se ela não pudesse ouvi-los, como se já não existisse." ${ }^{34}$ (NAŁKOWSKA, 2017, p. 35, tradução nossa). Como fugitiva, judia e baleada, ninguém ao seu redor consegue ver destino distinto à morte. Reforçam que o risco não vale: "Ninguém quis tirá-la dali antes do anoitecer, nem chamar um médico, nem a levar à estação, de onde poderia ir a um hospital. Nada disto estava previsto. A única questão era de que morreria, de um jeito ou de outro." ${ }^{35}$ (NAŁKOWSKA, 2017, p. 35, tradução nossa).

Os policiais discutem entre si então, quem vai atirar nela, já que este foi seu pedido. A indecisão de ambos traz novamente o personagem jovem que lhe comprou cigarros e vodca, e agora, com um tiro encerra sua história. Da neutralidade, rapidamente um homem passa a perpetrador do crime. Nałkowska mostra que este comportamento coletivo inerte, comum ao período, não soube dar destino diferente a esta mulher.

O conto fecha com um comentário do narrador duvidoso: “- Mas, por que ele atirou, não está claro - disse o narrador - Não posso compreender. Se parecia que exatamente esse homem sentia pena dela..." ${ }^{36}$ (NAŁKOWSKA, 2017, p. 36, tradução nossa). Nem o medo dos nazistas, nem a passividade da população, nem a fragilidade da mulher ferida são questionáveis ao narrador que os considera naturais diante dos fatos, mas sim a atitude gentil ou no mínimo caridosa do jovem. A violência sofrida, muito mais do que um tiro, foi a letalidade da abstenção coletiva, justificada por um desfecho inevitável, e não ideológico (TOKARSKA-BAKIR, 2019).

Há indícios históricos que possivelmente estejam relacionados a este acontecimento a partir de uma investigação feita em 1947 através de um relato local. Obviamente os fatos não coincidem por completo, mas são interessantes de serem comparados:

Um dia em 1942 [...] durante o inverno, eu fui para casa [ele morava na delegacia de polícia com o pai durante esse período]. Ao mesmo tempo, Muszyński [um policial] apareceu na delegacia [onde estava ocorrendo uma bebedeira], e ele propôs que eu fosse com ele até a ponte sobre o rio Uherka, o que fiz. Encontrei uma judia lá, escondida dos alemães. No caminho, quando estávamos conduzindo essa judia, não sei o sobrenome dela, peguei um rifle do chefe da Polícia Azul e atirei na judia naquela pequena ponte '. O policial que conduzia o interrogatório

\footnotetext{
${ }^{34}$ Original: „Mówili tak, jakby nie słyszała ich wcale, jakby jej już nie było.”.

${ }^{35}$ Original: "Tak więc nikt nie zapragnął zabrać jej stąd przed nocą ani wezwać doktora, ani odwieźć do stacji, skąd mogłaby pojechać do szpitala. Nic takiego nie było przewidziane. Szło już tylko o to, aby tak lub inaczej umarła.”.

${ }^{36}$ Original: “- Ale dlaczego on do niej strzelił, to nie jest jasne - mówił opowiadający. - Tego nie mogę zrozumieć. Właśnie o nim można było myśleć, że mu jej żal...”.
} 
fez algumas perguntas adicionais: o suspeito sabia em quem estava atirando e essa pessoa tentou fugir? A resposta foi a seguinte: 'Que judia não fez nenhuma tentativa de fugir de mim. [...] Eu sabia muito bem antes de atirar nela que ela era judia e estava se escondendo dos alemães. (TOKARSKA-BAKIR, 2019, p. 7).

A correspondência possível do relato com a história desta mulher, teria ocorrido no inverno de 1942-1943 na estrada Ruda-Huta, em um trajeto entre Chełm e Sobibor, o campo de destino. Esta, a judia de um povoado próximo, que teria um ferimento na cabeça, teve sua propriedade saqueada pelos poloneses que viviam no entorno. Seu assassinato teria ocorrido sobre a ponte Uherka, encorajado pelo policial que estava junto do jovem que o fez. $\mathrm{O}$ caso foi noticiado à polícia local. Nos relatos é possível perceber que esta não é uma situação isolada, mas frequente entre a polícia local e alguns moradores. Os tiros de misericórdia e compaixão justificaram o assassínio de muitos judeus durante a Shoah.

"Dwojra Zielona" é a narração sobre uma jovem judia faxineira, cega, que perde um olho no gueto e narra suas tragédias do gueto ao campo e até a libertação pelos soviéticos. É uma mulher completamente sozinha, e esta fala da ausência é uma das marcas do conto e como a protagonista que com seu nome intitula o texto se vê, sempre à beira da morte.

Dwojra é uma mulher de 35 anos, sem marido, morto no campo como lhe contaram, sem um olho, cega do outro e sem dentes. Também está sem seu sobrenome de casada, pela falta de documentos que o comprovem, Zielona é o sobrenome de seu pai. Seu relato sobre seu esconderijo no sótão do gueto quando das bombas e o período que lá ficou, longo na sua perspectiva, mas não preciso; com apena algumas cebolas, café e sem água; demonstra a inocência e juventude não condizentes com a gravidade dos acontecimentos:

Quando havia um ataque, eu sempre me escondia. Me metia no sótão. Tampou o rosto com ambas as mãos, separando os dedos. E por um instante olhou com seu único olho por entre os dedos.

Quer dizer que tampava o rosto com as mãos?

Sorriu.

Fazer o quê! Só estou te mostrando que sempre me escondia. (NAŁKOWSKA, 2017, p. 40, tradução nossa).

(Original: - Jak była akcja, to ja się zawsze schowałam. Siedziałam na strychu.

Rozpostartymi palcami obu rąk przesłoniła swą twarz. I patrzyła chwilę jednym okiem przez szpary między palcami.

- Czy to znaczy, że pani zakrywała sobie twarz rękami?

Uśmiechnęła się.

- Gdzie tam. Ja tylko pokazuję pani, że się tak zawsze chowałam.) 
A história da perda do olho foi fruto das comemorações de Ano Novo dos alemães no gueto, a morte de mais de sessenta e cinco judeus, incluindo toda sua família é a maneira dos nazistas de comemorar. Na tentativa de fugir ao pular pela janela, lhe acertam uma bala no olho. A força do seu relato está na incompreensão de Dwojra da sua vontade de viver mesmo diante de total ausência, paradoxo de toda a literatura de testemunho, entre a impossibilidade e a necessidade de narrar:

\begin{abstract}
Baixou a voz e disse em tom confidencial:
Devo dizer que eu queria viver. Não sei por que, já que não tinha marido, nem família, nem ninguém, e queria viver. Faltava um olho, tinha fome e frio, mas... queria viver. Por quê? Eu vou contar: para contar tudo, como conto agora a você. Para que o mundo soubesse o que eles fizeram.

Pensei que só sobreviveria eu. Pensei que não ficaria no mundo nem um só judeu. (NAŁKOWSKA, 2017, p. 41, tradução nossa).

(Original: Zniżyła głos, mówiła poufnie:

- Pani powiem: ja chciałam żyć. Nie wiem, bo nie miałam męża ani rodziny, ani nikogo, i chciałam żyć. Oka nie miałam, byłam głodna i chłodna - i chciałam żyć. Dlaczego? To pani powiem: po to, żeby powiedzieć wszystko tak, jak pani teraz mówię. Niech świat o tym wie, co oni robili.

Myślałam, że będę żyła tylko ja jedna. Myślałam, że nie będzie na świecie ani jednego Żyda.)
\end{abstract}

É no campo que perde a visão do outro olho numa conjuntivite, possivelmente relacionada as doze horas de trabalho diário na fábrica de munição. Todos seus dentes eram de ouro, e pela fome extrema, arrancou um a um durante meses para comprar pão. Sua voz repete o quanto queria viver e como nem todas as perdas lhe tiraram isso.

"Wiza", assim como o conto anterior, não exige tradução do título; por ser uma expressão sem tradução exata e que caracteriza a linguagem do lager, muito específica e multilinguística, já que os campos eram um espaço hermeticamente fechado com diversas nacionalidades sobrevivendo ou morrendo sob pressão extrema. O mais curto dos contos traz uma analogia através da narração de uma jovem judia que sobrevive aos campos se passando por polonesa, e enfatiza nas primeiras palavras do conto: "Não tenho nada contra os judeus. Como não tenho nada contra as formigas ou contra os ratos." ${ }^{37}$ (NAŁKOWSKA, 2017, p. 44, tradução nossa).

\footnotetext{
${ }^{37}$ Original: "Nie mam niechęci do Żydów. Tak samo jak nie mam niechęci do mrówki ani do myszki."
} 
A analogia animal, tão utilizada pela ideologia racial nazista está aqui expressa no conto na relação clássica entre gatos e ratos. Os judeus são desumanizados pela comparação constante com os ratos pelo Partido Nazista, no intento de reforçar um lado imundo e vil. A narradora conta uma história a respeito de um ninho de ratos dentro de uma batata, encontrado enquanto trabalhava descascando-as. Ela protege então três ratinhos recém-nascidos, não permitindo que os deem a um gato. A circunstância lhe acende esta analogia:

- Porque me ocorreu a seguinte ideia: Como o gato comerá os ratos?

E acrescenta com relutância:

- Havia em mim uma curiosidade como a de um membro da Gestapo: como seria?

Fica refletindo sobre um rato e este singular fenômeno, como se estivesse olhando pra dentro de si, e suspira.

- Assim os guardei de novo naquela casca, que escondi entre a palha. Talvez a mãe os encontraria e se salvariam.

De verdade não tem nada contra os judeus, apesar de ser cristã. (NAŁKOWSKA, 2017, p. 45, tradução nossa).

(Original: - Bo powstała we mnie taka myśl: a jak on będzie, ten kot, jadł te myszy?

I dodaje z niechęcią:

- Była we mnie taka ciekawość jak w gestapowcu - jak to będzie wyglądało?...

Zastanowiła się dłużej nad tym szczególnym zjawiskiem. Popatrzyła jak gdyby wewnątrz siebie i westchnęła.

- Więc schowałam je na powrót do tej łupki i zasunęłam głęboko w słomę. Może matka je znajdzie i jakoś się uratują.

Tak więc naprawdę nie ma niechęci do Żydów, mimo że sama jest chrześcijanką.)

"Wiza", o título do conto, é explicado pela judeu-polonesa como uma memória intensa que está viva em sua lembrança e lhe exige expressão. Wiza era um campo aberto, onde as mulheres judias ficavam de pé o dia todo, nuas, sem comer; para onde voltavam todos os dias por uma semana enquanto o bloco onde dormiam era desinfetado, mesmo no inverno.

A jovem cruza os acontecimentos atuais com os passados, fala sobre o que precisa fazer nos próximos dias, uma visita a uma amiga, uma ida ao hospital, devolver o dinheiro que lhe deram, pois não precisa dele. Uma mulher simples que evita falar de seus sofrimentos, apesar de sabermos que quebrou a perna e o osso não colou bem, por isso precisará voltar ao hospital. 
Ela faz digressões e avanços a respeito da vida e especialmente do que viu no campo. Mais que focada em contar, a memória do campo invade o discurso e a mente da testemunha, reiteradamente, fruto do modo obsessivo, repetitivo, porém incapaz de ser elaborado, como o trauma se manifesta. O final do conto apresenta uma cena trágica, mas que conserva sua beleza que ficou na memória desta polonesa:

- Um dia que também fazia frio, ao meio dia saiu o sol. Então todas se deslocaram até onde as árvores não as cobriam. Deslocaram-se não como pessoas, senão como animaizinhos. Ou como uma massa...

Exatamente neste dia as gregas cantaram o hino nacional. Não em grego. Cantaram o hino judeu em hebraico... Cantaram embaixo daquele sol de uma forma muito bonita, com voz forte e potente, como se estivessem sãs.

Não era força física, senhora, porque eram exatamente as mais débeis. Era a força da nostalgia e da esperança.

No dia seguinte houve uma seleção. Fui a wiza e a wiza estava deserta. (NAŁKOWSKA, 2017, p. 47, tradução nossa).

(Original: - Jeden dzień był też zimny, ale w południe pokazało się słońce. Wtedy one wszystkie przesunęły się w tę stronę, gdzie słońca nie zasłaniały drzewa. Przesunęły się nie jak ludzie, tylko jakby jakieś zwierzątka. Albo jakby jakaś masa...

Tego dnia właśnie Greczynki śpiewały hymn narodowy. Nie po grecku. One śpiewały po hebrajsku żydowski hymn... Śpiewały w tym słońcu bardzo pięknie, głośno i mocno, jakby były zdrowe. To nie była fizyczna siła, proszę pani, bo przecież one właśnie były najsłabsze. To była siła tęsknoty i pragnienia. Na drugi dzień była selekcja. Przyszłam na wizę i wiza była pusta.)

“Człowiek jest Mocny” (“O homem é forte”) é o penúltimo conto e o segundo que tem como personagem um homem, um jovem judeu que perde toda sua família asfixiada nas câmaras de gás e as encontra ele mesmo, mulher e filhos, ele mesmo passando pelo duplo trauma da perda e da obrigação em enterrá-los como parte do seu trabalho no bosque do campo de Chełmno.

"O homem é forte" permite ouvirmos a voz deste judeu Michał P. que descreve a chegada massiva de judeus ao campo e o caminho que percorriam até os crematórios, inclusive sua chegada e pedido para trabalhar no bosque. Seu pedido é fruto da perspectiva de fuga que vê ali. Descreve seu primeiro dia de trabalho:

Colocaram trinta de nós no caminhão e levaram ao bosque de Zuchów, deram picaretas e pás. Às oito da manhã chegou o primeiro caminhão de Chełmno. Quem trabalhava na fossa era proibido de virar para os 
caminhões, não deixavam olhar. Mas eu vi. Os alemães, ao abrirem as portas, se afastavam de um salto do caminhão. Do interior saía uma fumaça escura. No lugar onde estávamos, não sentíamos nenhum odor. (NAŁKOWSKA, 2017, p. 53, tradução nossa).

(Original: Zabrali nas trzydziestu, do samochodu, zawieźli do lasu Żuchowskiego, dali łopaty i kilofy. O ósmej rano przyjechał pierwszy samochód z Chełmna. Kto pracował w rowie, nie wolno było obrócić się do samochodów, nie dali patrzyć. Ale widziałem. Niemcy - jak otworzyli drzwi - odskoczyli od auta. Ze środka szedł ciemny dym. W miejscu, gdzieśmy stali, nie czuć było żadnego zapachu.)

Suas descrições detalhadas a respeito da forma que eram retirados dentes de ouro, relógios, dinheiro e anéis dos corpos por ucranianos lhe dão asco. Descreve nos dez dias que trabalhou ali, antes de sua engenhosa e bem-sucedida fuga, aquele que lhe é mais trágico:

- Um dia, era terça-feira, no terceiro caminhão que chegou de Chełmno descarregaram na terra os corpos da minha mulher e dos meus filhos, o menino tinha sete anos, a menina quatro. Então deitei sobre o corpo da minha mulher e disse que atirassem em mim.

"Não quiseram atirar. Um alemão disse: "O homem é forte, ainda trabalha bem." E me bateu com uma vara até que me levantei. (NAŁKOWSKA, 2017, p. 53, tradução nossa).

(Original: - Jednego dnia - to był wtorek - z trzeciego samochodu, który przyjechał tego dnia z Chełmna, wyrzucili na ziemię zwłoki mojej żony i moich dzieci, chłopiec miał siedem lat, dziewczynka cztery. Wtedy położyłem się na zwłokach mojej żony i powiedziałem, żeby mnie zastrzelili.

Nie chcieli mnie zastrzelić. Niemiec powiedział: "Człowiek jest mocny, może jeszcze dobrze popracować”. I bił mnie drągiem, dopóki nie wstałem.)

A cena final do conto é localizada no bosque onde Michał P. enterrou sua família, a narrativa descreve uma clareira sem vegetação e vida e os restos dos quatro fornos crematórios destruídos. A descrição se encerra com a chegada de duas mulheres solicitando a Comissão, portanto a autora surge como a narradora, perguntando se a exumação dos corpos poderia ser acelerada, pois sabiam exatamente onde estavam seu filho e marido.

Alguém mostrou um pedaço de uma caixa de fósforo com uma inscrição grega; outro, uns papelotes molhados com nomes de farmácias estrangeiras. Outro alguém, no lugar do antigo crematório, 
encontrou dois minúsculos ossos humanos. (NAŁKOWSKA, 2017, p. 54, tradução nossa).

(Original: Ktoś pokazywał znaleziony strzęp pudełka od zapałek $\mathrm{z}$ greckim nadrukiem, inny wymyte przez deszcze papierki $\mathrm{z}$ cudzoziemskimi firmami aptek. Ktoś na miejscu dawnego krematorium znalazł dwie malutkie kosteczki ludzkie.)

"Dorośli i Dzieci w Oświęcimiu” (“Adultos e crianças em Auschwitz”) é um conto nevrálgico ao final da obra, cumpre função oposta ao primeiro conto que introduz a temática e ambienta o leitor. Zofia Nałkowska aparece mais presente, como se este conto encarnasse sua percepção da guerra e da Shoah. Sintetiza o cenário amplo e complexo da Shoah através de seus principais locais de extermínio e concentração, centralizando sua narrativa no local mais icônico do genocídio: a cidade polonesa Oświęcim, conhecida por seu nome alemão dado durante a Segunda Guerra Mundial: Auschwitz.

À medida que se avança na narrativa, a trama incorpora os significados políticoeconômicos amplos da guerra ao lado da visão fria de cenas do horror, representação realista, e unicamente neste conto com mediação da autora, mesmo que muito comedida destes eventos inimagináveis.

"Adultos e crianças em Auschwitz", assim como no conto inicial, tem novamente personagens históricos nomeados e apresentados a partir de uma pergunta: “Que espécie de pessoas eram?"38 (NAŁKOWSKA, 2017, p. 58, tradução nossa); o cruel perpetrador August Glass que personifica na descrição do conto o que Todorov (2017) afirma ser uma ideologia como álibi e não como motivação do mal que se infringe. Também Himmler, Hitler e a juventude hitlerista são citados em contraposição a sobreviventes que trabalharam em favor das vítimas dentro do lager. Estes médicos e professores, como um contraponto extremo entre os médicos citados no conto Professor Spanner. Estes aqui, médicos de origem húngara e polonesa, simbolizando o país de origem da maior parte dos judeus mortos, além dos judeus tchecos.

O personagem central deste conto é coletivo: as vítimas. Esta reflexão traz além questionamentos sem fim. Katarzyna Chmielewska aponta que algumas das questões da Shoah amplamente debatidas no pós-guerra poderiam ser pensadas a partir de Medalhões: "Nałkowska permaneceu à margem. Ela não se tornou uma fonte real de perguntas e respostas no debate público polonês." (ŻUKOWSKI, apud GLIŃSKI, 2016, não paginado).

\footnotetext{
${ }^{38}$ Original: "Jacyż byli ci ludzie?"

Revista X, v. 15, n. 6, p. 583-611, 2020.
} 
O mote da obra através da frase "Pessoas prepararam esse destino a outras

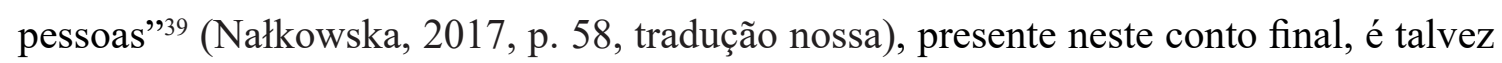
o ponto de maior impasse nas discussões sobre a obra. É uma epígrafe universalizante e por isso muito questionada por escritores e críticos. Grynberg, que nos anos 90 fez uma crítica extremamente positiva sobre a obra, ponderou apenas sobre a epígrafe humanista: "sempre que ela tentava adicionar seu comentário, ela cometia erros" (GRYNBERG, apud GLIŃSKI, 2000, não paginado) e para ele só poderia ser corrigida se ela fosse comparada à cena final da obra:

Uma ensolarada manhã de verão, o doutor Epstein, professor de Praga, andando pela rua entre os quarteirões do campo de Auschwitz, viu duas pequenas crianças ainda vivas. Estavam sentados na areia do caminho e mexiam nela uns pauzinhos. Deteve-se ao seu lado e perguntou:

O quê estão fazendo meninos?

E recebeu como resposta:

Estamos brincando de queimar judeus.

Primavera-verão de 1945 (NAŁKOWSKA, 2017, p .61, tradução

nossa).

(Original: Doktor Epstein, profesor z Pragi, przechodząc ulicą między blokami oświęcimskiego obozu w pogodny poranek letni, zobaczył dwoje małych dzieci jeszcze żywych. Siedziały w piasku drogi i przesuwały po nim jakieś patyczki. Zatrzymał się przy nich i zapytał:

- Co tu robicie, dzieci?

I otrzymał odpowiedź:

- My się bawimy w palenie Żydów.

Wiosna-lato 1945 r.)

A resposta dos meninos na cena encarna a Shoah e seu objetivo étnico da matança judaica que culturalmente impregnou a mentalidade coletiva durante a guerra. Grynberg argumenta que Nałkowska deveria ajustar o mote: "Pessoas prepararam este destino aos judeus". (GRYNBERG, apud GLIŃSKI, 2000, não paginado).

Nałkowska é plural e polifônica, e apresenta o topos histórico-literário da Shoah. Como Gliński (2020) claramente expôs, Medalhões é provocante e tem muitas tessituras ainda a serem discutidas e pode suscitar novas e mais profundas interpretações e perguntas sobre a Shoah, ampliando ou corrigindo o espaço que lhe cabe na literatura polonesa e na literatura de testemunho.

\footnotetext{
${ }^{39}$ Original: "Ludzie ludziom zgotowali ten los."
} 


\section{REFERÊNCIAS:}

BOROWSKI, Tadeusz. Utwory Zebrane. Tom II: Proza 1945-1947. Warszawa: Państwowy Instytut Wydawniczy, 1954.

BURYŁA, Sławomir; KRAWCZYŃSKA, Dorota; LEOCIAK, Jacek. Literatura Polska wobec Zagłady (1939-1968). Warszawa: Fundacja AII, IBL PAN, 2012.

DĄBROWSKA, Krystyna. Zofia Natkowska. Warszawa: Instytut Adama Mickiewicza, maio 2010. Disponível em: <https://culture.pl/pl/tworca/zofia-nalkowska $>$. Acesso em 21 fev. 2019.

HERLING-GRUDZIŃSKI, Gustaw. Medaliony Nałkowskiej. Wiadomości 31, 2, 1947.

FICOWSKI, Jerzy. A leitura das cinzas. Tradução de Piotr Kilanowski. Belo Horizonte: Âyiné, 2018.

GLIŃSKI, Mikołaj. Taking Polish Literature Out of Its Ghetto - An Interview with Ursula Phillips. Warszawa: Instytut Adama Mickiewicza, maio/jul. 2016. Disponível em: $<$ https://culture.pl/en/article/taking-polish-literature-out-of-its-ghetto-an-interview-withursula-phillips $>$. Acesso em 30 jul. 2018.

GLIŃSKI, Mikołaj. Zofia Natkowska's 'Medallions' \& The Bomb That Never Went Off. Warszawa: Instytut Adama Mickiewicza, 10 abr. 2020. Disponível em: $<$ https://culture.pl/en/article/zofia-nalkowskas-medallions-the-bomb-that-never-wentof $>$. Acesso em 25 jun. 2020.

GOMBROWICZ, Witold. Wspomnienia polskie. Wędrówki po Argentynie. In: GOMBROWICZ, Witold. Dzieła zebrane, tom 11, Paryż: Instytut Literacki, 1977.

GOMBROWICZ, Witold. O stylu Zofii Nałkowskiej. In: GOMBROWICZ, Witold. Proza (Fragmenty), Reportaże, Krytyka: 1933-1939. Kraków: Widawnictwo Literackie, 1995. p. 207.

KILANOWSKI, Piotr (Org.). Memórias de Luz: História de poloneses justos. Curitiba, PR: Casa da Cultura Polônia Brasil, 2015.

KIRCHNER, Hanna. Wstęp, opracowanie i przypisy. Dzienniki czasu wojny. In: NAŁKOWSKA, Zofia. Dzienniki czasu wojny. Warszawa: Czytelnik, 1970.

KUPREL, Diana. Introduction e translation from polish of Medaliony. Evanston, Illinois: Northwestern University Press, 2000. 
MORAWIEC, Arkadiusz. Deconstructing a Myth: Soap from Human (Jewish) Fat: Remarks on the Margins of Zofia Nałkowska's Short Story "Professor Spanner". Narracje o Zagładzie, 2016, n. 2, p. 133-149, 2016.

MORAWIEC, Arkadiusz. O "Medalionach" Zofii Nałkowskiej. Dopowiedzenia (w związku z ich genezą). In: Archiwa i bruliony pisarzy. Odkrywanie. Warszawa: Wydawnictwo Instytutu Badań Literackich PAN, 2017.

NAŁKOWSKA, Zofia. Dzienniki czasu wojny. Wstęp, opracowanie i przypisy Hanna Kirchner. Warszawa: Czytelnik, 1970.

NAŁKOWSKA, Zofia. Granica. Warszawa: Czytelnik, 1957.

NAŁKOWSKA, Zofia. Organizacja erotyzmu. Wiadomości Literackie, v. 9, n. 25, 19 jun. 1932.

NAŁKOWSKA, Zofia. Medaliony. Wrocław: Siedmioróg, 2017.

NAŁKOWSKA, Zofia. Medaliony. Kraków: Greg, 2016.

NAŁKOWSKA, Zofia. Medallions. Tradução de Diana Krupel. Evanston, Illinois: Northwestern University Press, 2000.

NAŁKOWSKA, Zofia. Medallones. Tradução de Bożena Zaboklicka e Francesc Miravitlles. Barcelona: Editorial Minúscula, 2009.

OLIVEIRA, Bruno R. de; OLIVEIRA, Flávia C.; RODRIGUES, Stéphanie P. (Org.) Noite dilacerada: poezja polaca de guerra. Edição bilíngue. Belo Horizonte: Viva voz/ FALE/UFMG, 2010.

SELIGMANN-SILVA, Márcio (Org.). História, Memória, Literatura: O testemunho na era das catástrofes. Campinas: UNICAMP, 2013.

SIEWIERSKI, Henryk. História da Literatura Polonesa. Brasília: UNB, 2000.

SOUZA, Marcelo Paiva de. Passados a construir: sobre Um outro mundo, de Gustaw Herling-Grudziński. Alea, Rio de Janeiro, v. 13, n. 2, p. 252-272, jul./dez. 2011.

SPRUSINSKI, Michał. Contos Polacos. Tradução de José Saramago. Lisboa: Editorial Estampa, 1977.

SZLENGEL, Władysław. A janela para o outro lado: poemas do gueto de Varsóvia. Organização, tradução e notas de Piotr Kilanowski. Fortaleza: Dybbuk, 2018. 
SZULC, Sylwia. Accepted, rejected, unknown: the impact of world politics and publishing policies since 1945 on the translation into english of polish novels and short stories of the 1945-1989 period. 2017. 410 f. PhD dissertation (PhD in English Studies) - Faculty of Modern Languages, Institute of English Studies, University of Warsaw, Wasrsaw, 2016.

TODOROV, Tzvetan. Diante do extremo. São Paulo: Editora Unesp, 2017.

TOKARSKA-BAKIR, Joanna. Zofia Nałkowska's By the Railway Track. Historical precedent and literary adaptation. Versão alemã „Am Bahngleis“ von Zofia Nałkowska: Geschichte und literarische Transformationen. In: KOBYLINSKA-DEHE, Ewa; DYBEL, Pawel; HERMANNS, Ludger M. (Orgs.) Im Schatten von Krieg und Holocaust. Psychoanalyse in Polen im polnisch-deutsch-jüdischen Kontext. Gießen: PsychosozialVerlag, 2019. p. 69-85.

ŻUKOWSKI, Tomasz (Org.); PUERTA, Aránzazu Calderón; CHMIELEWSKA, Katarzyna; HOPFINGER, Maryla; UMIŃSKA, Bożena; WILCZYK, Wojciech. Zagłada w "Medalionach" Zofii Nałkowskiej: tekst i konteksty. Warszawa: Instytut Badań Literackich PAN Wydawnictwo, 2016. 